\title{
Necrotizing enteritis associated with Clostridium perfringens Type B in chinchillas (Chinchilla lanigera) ${ }^{1}$
}

\author{
Ricardo B. Lucena², Luana Farias ${ }^{2}$, Felipe Libardoni² ${ }^{2}$ Agueda C. Vargas ${ }^{3}$, Paula R. \\ Giaretta $^{4}$ and Claudio S. L. Barros ${ }^{5}$
}

\begin{abstract}
Lucena R.B., Farias L., Libardoni F., Vargas A.C. Giaretta P.R. \& Barros C.S.L. 2011. Necrotizing enteritis associated with Clostridium perfringens Type B in chinchillas (Chinchilla lanigera). Pesquisa Veterinária Brasileira 31(12):1071-1074. Departamento de Patologia, Universidade Federal de Santa Maria, Camobi, Santa Maria, RS 97105900, Brazil. E-mail: claudioslbarros@uol.com.br

Four 3-4 month-old chinchillas (Chinchilla lanigera) from a commercial flock of 395 chinchillas, were found dead with evidence of previous diarrhea and prolapsed rectum. A fifth 8 month-old chinchilla died 8 hours after being found recumbent, apathetic, diarrheic and with a prolapsed rectum. Two chinchillas were necropsied and observed gross lesions consisted of extensive hemorrhagic enteritis, mild pulmonary edema and enlarged and yellow liver; this latter finding was particularly prominent in the chinchilla presenting longer clinical course. Histologically there was necrotizing enteritis associated with abundant bacterial rods aggregates in the intestinal surface epithelium and within the lamina propria. In the lungs there were small amounts of pink proteinaceous material (edema) in the interstitium and marked vacuolar hepatocellullar degeneration (lipidosis) in the liver. Anaerobic cultures from the intestinal contents of one of the affected chinchillas yielded Clostridium perfringens. Genotyping of this $C$. perfringens isolate was achieved by multiplex polymerase chain reaction (mPCR) as $C$. perfringens type B due to detection of alpha, beta and epsilon-toxin genes. These findings suggest $C$. perfringens type $B$ as an important cause of sudden or acute death in chinchillas.
\end{abstract}

INDEX TERMS: Diseases of chinchilla, pathology, Clostridium perfringens, enterotoxemia, intestinal infection.

RESUMO.- [Enterite necrosante associado a infecção por Clostridium perfringens tipo B em chinchilas (Chinchilla lanigera).] Quatro chinchilas (Chinchilla lanigera) com 3-4 meses de idade, pertencentes a um criadouro comercial com 395 chinchilas, foram encontradas mortas com evidências de diarreia prévia e prolapso de reto. Uma quinta chinchila, de oito meses de idade, foi encontrada em decúbito, apática,

\footnotetext{
${ }^{1}$ Received on August 16, 2011.

Accepted for publication on September 5, 2011.

${ }^{2}$ Programa de Pós-Graduação em Medicina Veterinária, Centro de Ciências Rurais (CCR), Universidade Federal de Santa Maria (UFSM), Camobi, Santa Maria, RS 97105-900, Brazil.

${ }^{3}$ Departamento de Medicina Veterinária Preventiva, CCR-UFSM, Santa Maria, RS.

${ }^{4}$ Graduação em Medicina Veterinária, Laboratório de Patologia Veterinária, CCR-UFSM, Santa Maria, RS.

${ }^{3}$ Departamento de Patologia, Centro de Ciências da Saúde, UFSM, Avenida Roraima 1000, Santa Maria, RS 97105-900, Brasil. *Corresponding author: claudioslbarros@uol.com.br
}

com diarreia e prolopaso de reto, e morreu após oito horas. Duas chinchilas foram submetidas à necropsia. As lesões macroscópicas consistiam de extensa enterite hemorrágica, moderado edema pulmonar e fígado pálido e aumentado de volume; este achado foi particularmente proeminente na chinchila que apresentou curso clínico mais longo. Histologicamente foi observado enterite necrosante associada a numerosos agregados bacterianos na superfície epitelial com invasão da lâmina própria. Nos pulmões foi observada pequena quantidade de material proteináceo róseo amorfo (edema) no interstício e marcada degeneração hepatocelular vacuolar (lipidose). Cultura anaeróbica do conteúdo intestinal de uma chinchila afetada revelou crescimento de Clostridium perfringens. A genotipificação de C. perfringens isolado, realizada por reação em cadeia de polymerase multiplex (mPCR), revelou C. perfringens tipo B pela detecção das tóxinas alfa, beta e épisilon. Estes achados sugerem que infecção por C. perfringens tipo B é uma importante causa de morte súbita ou aguda em chinchilas. 
TERMOS DE INDEXAÇÃO: Doenças de chinchilas, patologia, Clostridium perfringens, enterotoxemia, infecção intestinal.

\section{INTRODUCTION}

Clostridium perfringens is a Gram-positive, anaerobic, rod-shaped, spore forming, oxygen-tolerant anaerobe which is a common inhabitant of the intestine of human beings and animals, but is also found in the environment (Songer 1996). C. perfringens is classified in five toxinotypes (AE), according to the production of 4 major toxins (alpha [CPA], beta [CPB], epsilon [ETX], and iota [ITX]) (Hatheway 1990). C. perfringens type B produces alpha, beta and epsilon toxin (Uzal \& Songer 2008). CPA, the main lethal toxin of $C$. perfringens, is a multifunctional phospholipase, produced in varying amounts by almost all $C$. perfringens isolates. It causes hydrolysis of membrane phospholipids in different cells, resulting in lysis. It is lethal to mice, guinea pigs and rabbits when administered parenterally and causes hemolysis of erythrocytes of some animal species in vitro (Coetzer \& Tustin 2004). CPB is a major virulence factor of Clostridium perfringens. The biological function of this lethal toxin has been largely unclear, although it is known to be an important factor in the pathogenesis of necrotic enteritis in humans and animals with a lethal pore-forming toxin (Steinthorsdottir 2000). The toxin apparently induces the release of catecholamines that are responsible for the increased blood pressure (Sakurai et al 1984). When injected i.d. into guinea pigs, a minimum dose of 2 ng causes purple areas of dermatonecrosis (Hatheway 1990). Epsilon toxin is produced as a prototoxin that is activated by proteolytic enzymes produced by the same organism (the kappaand lambda-toxins), or it can be activated by adding trypsin to the culture (Hatheway 1990). The gene for the production of epsilon toxin is thought to reside on a plasmid and is found only in strains of $C$. perfringens types B and D (Songer 1996). Epsilon-toxin primarily affects the intestine by increasing permeability of the gut wall, thus enhancing its own uptake, and acts systematically as a lethal toxin (Buxton 1978). After entering the circulation, it causes swollen hyperemic kidneys, edema in the lungs, and excess pericardial fluid (McDonel 1980). Small amounts of ETX detected in the gut of normal animals are considered innocuous, but persistence of high concentrations can be highly lethal; by increasing intestinal permeability and due to absorption into the circulation the toxin primarily targets the central nervous system, where it produces perivascular edema, hemorrhages and necrosis (Songer 1996).

Documentation of enteric disease by $C$. perfringens in chinchillas is rare and includes reports of the disease caused by type D (Newberne 1953, Moore \& Greenlee 1975 ) and type A $C$. perfringens (Bartoszcze et al. 1990). These reports describe the clinical and microbiological aspects of the disease but little attention is drawn to the gross and histopathological lesions. Enteric disease in chinchillas caused by C. perfringens type B is apparently unreported.

The current study reports the occurrence of sudden deaths associated with necrotizing enteritis in chinchillas associated with $C$. perfringens type B toxi-infection and re- ports on the gross and histopathological lesions as well on the use of multiplex polymerase chain reaction (mPCR) to confirm the diagnosis of the condition.

\section{MATERIALS AND METHODS}

An outbreak of sudden deaths observed in chinchillas from a commercial flock located in Southern Brazil. In this flock, comprising 395 chinchillas of various ages, four 3 to 4-month-old chinchillas (Chinchillas 1-4) were found dead. Liquid dark brown feces were adhered to the hairs of perianal region indicating previous diarrhea. Another chinchilla (Chinchilla 5) was found apathetic, diarrheic and with prolapsed rectum. Clinical course from the observation of first signs to death in Chinchilla 5 was 8 hours. Complete necropsies were performed in two chinchillas (chinchillas 4 and 5) and fragments of the following organs were sample in 10\% buffered formalin: heart, lung, liver, spleen, kidney, brain, skeletal muscle, small and large intestine. After 24 hours of fixation the specimens were routinely processed for histopathology, sectioned to 4 $\mu \mathrm{m}$ and stained by hematoxylin and eosin. Intestinal contents and feces from one animal (Chinchilla 5) was cultured both aerobically and anaerobically on 5\% sheep blood Agar; cultivated micro-organisms were identified through morphological and tinctorial characteristics and, after identification, isolated for further molecular characterization. C. perfringens DNA was extract by the CTAB (Cetyltrimethylammonium bromide) method (Sambrook \& Russell 2001). Genotyping of the $C$. perfringens isolate was performed through multiplex polymerase chain reaction (mPCR) using specific primers for the toxin genes for cpa, cbp, itx, etx and cpe (enterotoxin) and methods described elsewhere (Meer \& Songer 1997) (Table 1). Eight $\mu \mathrm{l}$ from the product of PCR were submitted to $1.5 \%$ agarose gel electrophoresis, stained with ethidium bromide and examined through ultraviolet transillumination.

Table 1. Sequence of the primers used in the multiplex PCR for amplification of genes encoding toxins and Clostridium perfringens types

\begin{tabular}{ccccc}
\hline Gene* & Toxin & Sequence 5' - 3' & $\begin{array}{c}\text { Product } \\
(\mathrm{bp})^{* *}\end{array}$ & Types \\
\hline $\boldsymbol{c p \boldsymbol { a }}$ & $\boldsymbol{\alpha}$-toxin & $\begin{array}{c}\text { GCTAATGTTACTGCCGTTGACC } \\
\text { TCTGATACATCGTGAAG }\end{array}$ & 324 & A, B, C, D, E \\
$\boldsymbol{c p \boldsymbol { b }}$ & $\beta$-toxin & $\begin{array}{c}\text { GCGAATATGCTGAATCATCTA } \\
\text { GCAGGAACATTAGTATATCTTC }\end{array}$ & 196 & B, C \\
$\boldsymbol{i a p}$ & --toxin & $\begin{array}{c}\text { ACTACTCTCAGACAAGACAG } \\
\text { CTTTCCTTCTATTACTATACG }\end{array}$ & 446 & E \\
$\boldsymbol{e t \boldsymbol { x }}$ & $\boldsymbol{\varepsilon}$-toxin & $\begin{array}{c}\text { GCGGTGATATCCATCTATTC } \\
\text { CCACTTACTTGTCCTACTAAC }\end{array}$ & 655 & B, D \\
$\boldsymbol{c p} \boldsymbol{e}$ & $\begin{array}{c}\text { entero- } \\
\text { toxin }\end{array}$ & $\begin{array}{c}\text { GGAGATGGTTGGATATTAGG } \\
\text { GGACCAGCAGTTGTAGATA }\end{array}$ & 233 & A, B, C, D, E
\end{tabular}

* Oligos for the major toxin genes of Clostridium perfringens (Meer et al. 1997), ** Base par.

\section{RESULTS}

The gross and histopathological findings in the two necropsied chinchillas were mainly restricted to the intestines and were more marked in Chinchilla 5. Necropsied animals were in good body condition. The small intestine was distended by gas and was markedly reddened (Fig.1). The intestinal content was liquid and hemorrhagic and the mucosal surface was diffusely reddened, necrotic and covered by fibrin. Mild edema was observed in the lung. The liver was enlarged with rounded edges and the hepatic parenchyma was yellow, greasy and more friable than normal (hepatic 
lipidosis); this latter change was particularly marked in chinchilla 5. No Gross changes were observed in the other organs. Histologically, there was coagulative necrosis and loss of the jejunal lining epithelium. The epithelial deprived areas were covered by a meshwork of fibrin and entrapped neutrophilic inflammatory cell infiltrate, necrotic cells consisting of cell debris, associated with hemorrhage and numerous basophilic bacilli aggregates (Fig.2). The lamina propria underneath was marked infiltrated by plasma cells, lymphocytes and neutrophils with intralesional bacilli aggregates. Diffusely in the liver there was marked hepatocellular vacuolation which peripheralizes the hepatocyte nuclei (hepatic lipidosis). In the lungs there were small amounts of pink proteinaceous material (edema) in the interstitium. No lesions were found in the remaining organs sampled at necropsy for histopathological examination.

Clostridium perfringens was isolated from the intestinal content of chinchilla 5 and grew only in holding jars with

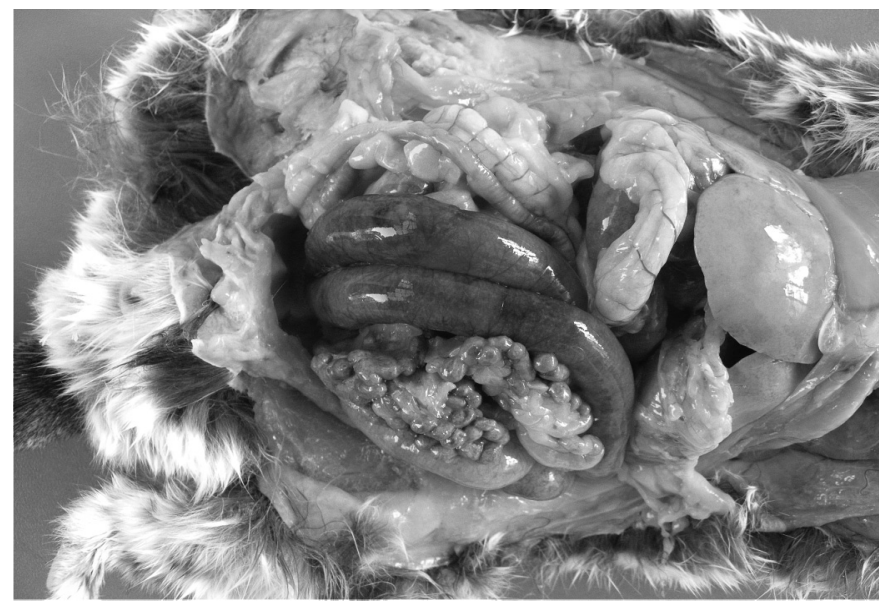

Fig.1. Clostridium perfringens type B necrotizing enteritis in Chinchilla 5 . The intestine is distended by gas and bloddy fluid; the intestinal serosa is markedly reddened. Note the pale and enlarged liver (hepatic lipidosis).

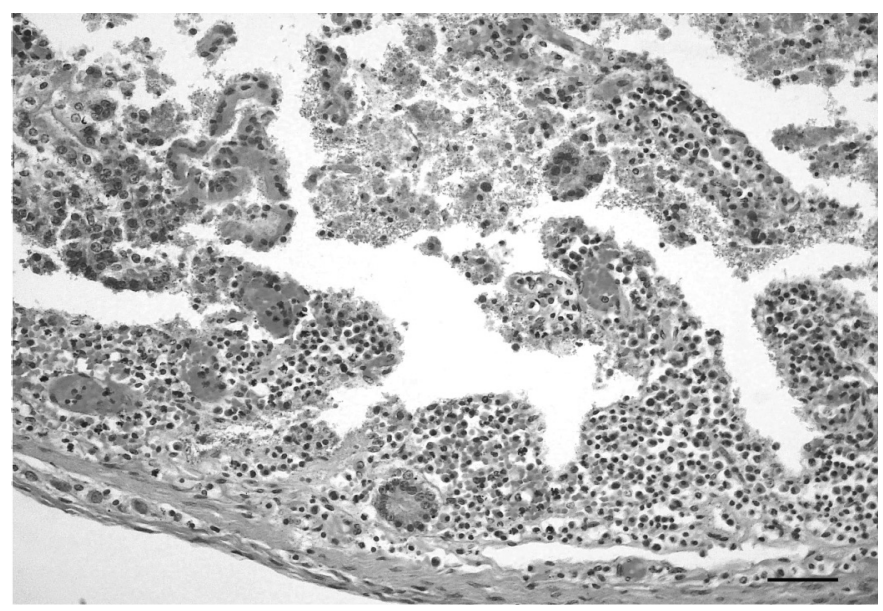

Fig.2. Photomicrograph of the small intestine in Chinchilla 5 showing necrotizing enteritis caused by Clostridium perfringens type B. Observe extensive necrotic areas of the intestinal epithelial and myriads of bacilli aggregates admixed with fibrin, cell debris and inflammatory cells within the lumen. Hematoxylin and eosin, obj.20x. Bar $=100 \mu \mathrm{m}$. an $\mathrm{O}_{2}$ free atmosphere at $37^{\circ} \mathrm{C}$. Colonies on blood agar showed a characteristic double-zone hemolysis around the colony: an inner clear zone due to theta-toxin; and an outer hazy zone due to CPA toxin. Gram staining, organisms were short gram-positive rods. By using mPCR the sample amplified the fragments of cpa (324 bp), cpb (196 bp) e etx (655 bp) genes visualized in agarose gel (1.5\%) (Fig.3) which allowed genotyping of the isolate as $C$. perfringens tipo B (Meer \& Songer 1997).

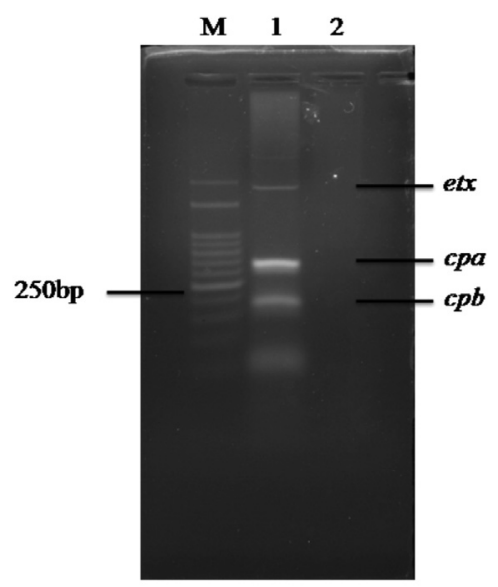

Fig.3. Agarose gel (1,5\%) electrophoresis of multiplex Clostridium perfringens PCR. Lane M: size marker (Ludwig 50bp DNA ladder). Lane 1: $\mathrm{Cl}$. perfringens type B isolate from Chinchilla lanigera. Lane 2: negative control. The amplified PCR products of beta (cpb), alpha (cpa) and epsilon-toxin (etx) are 196, 324 and $655 \mathrm{bp}$, respectively.

\section{DISCUSSION}

The tentative diagnosis of intestinal infection by Clostridium perfringens was made based on clinical presentation (sudden death) and pathological findings of necrotizing enteritis associated with great numbers intralesional bacilli. The establishment of $C$. perfringens type B as the cause of the enteric condition was achieved by anaerobic bacteriological culture of the organism and the detection by PCR of the toxin genes $c p a, c p b$ and etx. Although the toxin detection in the intestinal contents are indicated, it was not performed in the current cases due to the fast degradation of the toxins after death by the trypsin produced in the intestinal lumen (Sakurai \& Duncan1978). However the fact that Clostridium organisms are not normal constituents of the intestinal flora in chinchilla and that there no reports of C. perfringens type B supports our diagnosis.

The infection by $C$. perfringens is considered to be the most important cause of clostridial enteric disease in animals (Songer 1996) and deaths caused by C. perfringens type A (Bartoszcze et al. 1990) and D (Newberne 1953, Moore \& Greenlee 1975) infections have been reported in chinchillas. In these previously described outbreaks the outcome of the illness was sudden deaths similarly to what was observed in the affected animals of this report. As was the case in the affected chinchillas from the current report, the reported deaths of chinchillas due to enteric infection by $C$. perfringens type A (Bartoszcze et al. 1990) was asso- 
ciated with severe necrotizing enteritis; the reported centrolobular hepatic necrosis and splenic white pulp hyperplasia found in $C$. perfringens type infection (Bartoszcze et al. 1990) was not present in the chinchillas of this report. Severe hepatic lipidosis was a consistent finding in the affected chinchillas of this report. Hepatic lipidosis is a fairly common necropsy finding in chinchillas in a good nutritional plane that are submitted to alimentary restriction due to lack o food or illnesses- related anorexia (our unpublished data) and can not be construed as a specific lesion for any disease in particular. Most likely this is a lesion associated to increased hepatic influx of fatty acids due their mobilization from fat deposits for energy supply.

Enteric $C$. perfringens infections in farm animals and other species are generally called enterotoxemia because toxins produced in the intestine are absorbed in the general circulation and exert their action systemically (Uzal \& Songer 2008). However, although this is true for many of C. perfringens toxins, some toxins produced in the intestine act only locally, as is the case of hemorrhagic enteritis produced by $C$. perfringens type B in small ruminants (Uzal \& Songer 2008). In the cases of chinchillas reported here the lesions were basically restricted to the intestines in the form of necrotizing enteritis. No signs of systemic toxin action were evident; therefore it was preferred to name the condition by its main morphological diagnosis. However enterotoxemia is not excluded in these cases and actually probably occurred, since sudden or acute deaths associated with enterocolitis have been described in goats with enterotoxemia due to C. perfringens type D (Uzal et al. 2008).

Predisposing factors for $C$. perfringens type B induce necrotizing enteritis have not been investigated in chinchillas. C. perfringens is commonly found in the intestines of animals does not exhibit adherence and invasive properties towards healthy intestinal mucosa (Songer 1996). The disease manifests itself especially when there is sudden change in feeding to highly fermentable carbohydrates (Radostits et al. 2007). Information on possible dietary changes in the chinchillas of this report was not available and therefore it is not possible to speculate on the predisposing factors in this particular instance.

The results presented here suggest that $C$. perfringens type B enteric infection is an important etiology to be considered in cases of sudden or acute deaths in chinchillas. PCR could be an useful diagnostic aid in such cases.

Aknowledgements.- This study was financially supported by the Brazilian agency National Council of Scientific and Technologic Development (CNPq), Grant 473493/2010-1.

\section{REFERENCES}

Bartoszcze M., Nowakowska M., Rozskowski J., Matras J., Palec S. \& Wystup E. 1990. Chinchilla deaths due to Clostridium perfringens A enterotoxin. Vet. Rec. 126:341-342.

Buxton D. 1978. Further studies on the mode of action of Clostridium welchii type D epsilon toxin. J. Med. Microbiol. 11:293-298.

Coetzer J.A.W. \& Tustin R.C. 2004. Clostridium perfringens group infections, p.1819-1828. In: Ibid. (Eds), Infections Diseases of Livestock. Vol.3. $3^{\text {rd }}$ ed. Oxford University Press, New York, NY.

Hatheway C.L. 1990. Toxigenic clostridia. Clin. Microbiol. Rev. 3:66-98.

McDonel J.L. 1980. Clostridium perfringens toxins (type A, B, C, D, E). Pharmacol. Ther. 10:617-655.

Meer R.R. \& Songer J.G. 1997. Multiplex polymerase chain reaction assay for genotyping Clostridium perfringens. Am. J. Vet. Res. 58:702-705.

Moore R.W. \& Greenlee H.H. 1975. Enterotoxemia in chinchillas. Lab. Anim. 9:153-154.

Newberne P.M. 1953. An outbreak of bacterial gastroenteritis in South American chinchilla. North. Am. Vet. 34:187-188.

Radostits O.M., Gay C.C. \& Hinchcliff K.W. \& Constable P.T. 2007. Veterinary Medicine. $10^{\underline{a}}$ ed. Saunders Elsevier, Edinburgh, UK.

Sakurai J. \& Duncan C.L. 1978. Some properties of beta-toxin produced by Clostridium perfringens type C. Infect. Immun. 21:678-680.

Sakurai J, Fujii Y, Dezaki K \& Endo K. 1984, Effect of Clostridium perfringens beta toxin on blood pressure of rats. Microbiol. Immunol. 28:23-31.

Sambrook J. \& Russell D.W. 2001. Molecular cloning, p.1.149, 6.61-6.62, 16.33-16.41. In: A Laboratory Manual. $3^{\text {rd }}$ ed. Cold Spring Harbor Laboratory Press, Cold Spring Harbor, NY.

Songer J.G. 1996. Clostridial Enteric Diseases of Domestic Animals. Clin. Microbiol. Rev. 9:216-239.

Steinthorsdottir V., Halldórsson H. \& Andreósson O.S. 2000. Clostridium perfringens beta-toxin forms multimeric transmembrane pores in human endothelial cells. Microb. Pathog. 28:45-50.

Uzal F.A. \& Songer J.G. 2008. Diagnosis of Clostridium perfringens intestinal infections in sheep and goats. J. Vet. Diagn. Invest. 20:253-265.

Uzal F.A., Fish D.J., Saputo J., Sayeed S., McClane B.A., Songer G., Trinh H.T., Fernandez M.M.E. \& Gard S. 2008. Ulcerative enterocolitis in two goats associated with enterotoxin- and beta2 toxin-positive Clostridium perfringens type D. J. Vet. Diagn. Invest. 20:668-672. 